\title{
Politics of Water Resource Management in the Indus River Basin: A Study of the Partition of Punjab
}

\author{
Muhammad Nawaz Bhatti* \\ Department of Politics and International Relations, University of Sargodha, Pakistan.
}

Received: August 1, 2020

Published Online: November 14, 2020

\begin{abstract}
The British Government of India divided the Muslim majority province of Punjab into Eastern and Western Punjab. But the partition line was drawn in a manner that headworks remained in India and irrigated land in Pakistan. The partition of Punjab was not scheduled in the original plan of the division of India. Why was it partitioned? To answer this question, the study in the first instance tries to explore circumstances, reasons, and conspiracies which led to the partition of Punjab which led to the division of the canal irrigation system and secondly, the impact of partition on water resource management in the Indus River Basin. Descriptive, historical, and analytical methods of research have been used to draw a conclusion. The study highlights the mindset of Indian National Congress to cripple down the newly emerging state of Pakistan that became a root cause of the partition of Punjab. The paper also highlights why India stopped water flowing into Pakistan on $1^{\text {st }}$ April 1948 and the analysis also covers details about the agreement of $4^{\text {th }}$ May 1948 and its consequences for Pakistan.
\end{abstract}

Keywords: Punjab Partition, Boundary Award, Impact of Partition, Indus River Basin, Water Resource Management, Pak-India Water Dispute.

\section{Introduction}

Water is the basic necessity of life, and precipitation is its fundamental source. The maximum area of the Indus Rivers Basin lies in arid or semi-arid climatic zones. So, waters of the Indus Rivers System always played a vital role to sustain life in the region. After World War II, when the British finally decided to leave, the Muslims being worried about their future demanded the partition of India, the Hindus bitterly opposed the idea of partition. In their opposition to a Muslim state (Pakistan), they maneuvered the support of Sikhs five million of whom were concentrated only in Punjab, and demanded the partition of the Muslim majority province of Punjab. Ultimately, their demand was accepted by the British Government and the Province was divided into Eastern and Western Punjab. But the partition line was drawn in a manner that headworks remained in India and irrigated land in Pakistan. Being an upper riparian and having the control of headworks, India stopped the water in every canal flowing into Pakistan on $1^{\text {st }}$ April 1948. That Indian action highly aggravated already tense relations between India and Pakistan. This paper is an attempt to highlight the reasons and events of the partition of Punjab which led to the division of the canal irrigation system and its impact on water management and development in the Indus River Basin. 
People of India had struggled for a long time to get freedom from the alien rule of the British. At the end of the Second World War, the British Government ultimately decided to leave India. But it was not a country in which they could hand over power to its natives and quit. It was a land of diverse religious communities. Hindus were in dominant majority and Muslims were the second largest nationality. The Muslims were worried about the Hindu majority in any future democratic system. They demanded that before the British left, India should be divided into two sovereign states. The Muslim-majority regions should form a separate independent state named Pakistan. Hindus bitterly opposed the division of India. Mahatma Gandhi, the venerated leader and patron of the Indian National Congress (INC) deemed it as bisection of "gao mata" (mother cow), held holy by the Hindus (Qadri, 1983; Khan, 2017).

In their opposition to Pakistan, Hindus manoeuvred support of Sikhs who were five million concentrated only in Punjab and demanded the partition of Punjab. A Hindu-Sikh nexus was formed against Pakistan. Early in March 1947, Sikh leader Master Tara Sing ${ }^{1}$ standing side by side with Congress leader Lala Bhim Sen Sachar on the steps of the Punjab assembly building, proclaimed, "Sikhs were ready and that the might of sword alone shall rule". (Chatterjee, 2018). In the start of June 1947, the Sikh leadership held a meeting at Nedou's Hotel in Lahore to decide Sikh strategy in case the partition of India was decided. Master Tara Singh stated in his speech "Oh Sikhs, be ready for self-destruction like Nazis and Japanese....our motherland is calling for blood" (Collins \& Lapierre, 1997).

Tara Singh's statements created a situation of tension as communal disturbances started all over Punjab. INC fully supported the agitation of Sikhs and demanded the partition of Punjab. Muslims stood firm in their demand for a separate homeland defying all forces of opposition. INC and the British accepted the reality of Pakistan ultimately. It shattered the Hindu dream of Akhand Bharat (United India). INC tried to cripple the emerging State of Pakistan in whatever way possible. Collins \& Lapierre (1997: 126) wrote: "It was over her share of the goods of the old Indian army, however, that Pakistan encountered Indian bad faith .... deliberate effort to jeopardize her survival". For instance, under the partition agreement, Pakistan was allotted seventeen thousand tons of army stores but got only 6000. For carrying arms and ordinance, 300 special trains were deputed to Pakistan, but only three reached their destination.

Elaborating their point they further write, "This trickery left bitter memories in Pakistan and a deep-seated conviction among many that their Indian neighbours were trying to strangle them in their cradle". Pakistanis were not alone in that strong belief. Field Marshal Sir Claude Auchinleck, (Commander-in-Chief of the armed forces in India), who was responsible for the distribution of the armies' goods, informed the British Prime Minister that the present Indian Government was determined to prevent Pakistan receiving her just share, or indeed anything of the large stocks of reserve arms, equipment, stores, etc. held in the arsenals and depots in India (Sayeed, 1998). He further stated that "I am sure that present Indian Cabinet is fully determined to prevent the establishment of Pakistan" (Collins \& Lapierre, 1997: 145). This kind of mindset determined Hindu attitude towards Pakistan during the partition. Keeping in view the above narrated INC mindset, one can easily understand why INC supported the demand of Sikhs for the partition of Punjab. Lord Mountbatten also facilitated INC leadership to fulfil their demands to secure his vested interests.

\section{Methods and Material}

This study is qualitative, descriptive, and analytical in nature that aims to describe the reasons 
and impact of the partition of Punjab in 1947. After describing the background of the partition of Punjab, this paper analyses the events and consequences of partition very comprehensively, especially water politics. Both primary and secondary sources of data have been used to find the results. Secondary data includes various books, magazines, experts' discussions, research articles, and websites. Like other doctrinal and security studies, this research does not claim to address the issue in its completeness; however, one of the way forward to understand the fault lines emerged after the partition of Punjab in India and Pakistan that changed entire politics of Indian subcontinent. Several research articles, newspapers, and books related to the partition of Punjab were examined to investigate the reasons behind that tragic event more specifically. The focus of this study is to explore the impact of partition on water resource management in the Indus River Basin. The content analysis technique has been used to analyze the collected data.

\section{The Partition of Punjab: An Appraisal}

\subsection{The Deal between Lord Mountbatten and Indian National Congress}

On June 3, 1947, the Government of Britain announced the final plan for the partition of India. It was to be implemented by June 1948 as initially announced but was done on August 15, 1947. India was a large sub-continent. It comprised a dozen provinces governed by the British. Besides, there were 562 large and small states ruled by Indian princes. To partition the country into two independent states in just 73 days was unprecedented. For instance, when Burma was separated from British India in 1937, it took two years. Likewise, the division of the Bombay Presidency in 1935 to form Sindh as a separate province took two years to complete the process (Malik, 2005). So, one can raise a question about hurried partition. It was a deal between Mountbatten and the INC for a very early transfer of power in return for acceptance of Dominion Status and Lord Mountbatten as the first Governor-General of India. It was clear to everyone that the process of partition could not possibly be completed within only two months. So some provision to resolve the unsettled issues had to be made. Mountbatten's solution was that he should continue as a common Governor-General of India and Pakistan for eight or nine months from August 15, 1947, onward (Ali, 1973: 174).

The British Government was conscious about keeping both India and Pakistan in the British Commonwealth. Mr. Jinnah had already declared in the first week of April 1947 that Pakistan would join the Commonwealth, whereas INC was not willing to join it and it declared time and again that India would be a Republic. So, INC cut a deal with Lord Mountbatten through V. P. Menon, a senior advisor on Mountbatten's staff through which India's inclusion in the British Commonwealth and Mountbatten's appointment as the first Governor-General of India was ensured (Malik, 2005: 58; Pardesi \& Ganguly, 2019). On May 1, 1947, V. P. Menon conveyed Sardar Patel's message to Lord Mountbatten. According to Pyarelal (1956), the secretary of Mr. Gandhi, Congress offered that it could accept Dominion Status and Lord Mountbatten as the first Governor-General of India provided, power must be transferred within two months.

On the other hand, Mr. Jinnah did not agree to the proposal of the common Governor-General due to so many constitutional and political reasons. Mountbatten was bitterly wounded. His dream to be the common Governor-General was shattered. Ali (1973: 177) describes the feelings of Mountbatten in the following words when one day he was working with Mr. Jinnah and Liaqat Ali Khan on the Indian Independence Bill in the Viceroy House: 
"He explained to Mr. Jinnah with arguments, appeals, and bluster. He claimed that the proposal for a common Governor-General was inspired by the highest motives and was in the best interests of Pakistan. Without him as a common Governor-General, Pakistan would put itself at the gravest disadvantage".

He further writes that "from that time, there was a noticeable change in Mountbatten's attitude towards Pakistan and the problems of partition. Mountbatten had barely tolerated Jinnah in the past; now there was active hostility". On the other side, Jinnah was still convinced about Mountbatten's fairness and refused to see any change in him even when others pointed it out to him. The decision of Jinnah against the common Governor-General had severe effects on Pakistan. The loss Pakistan faced regarding the material assets was easy to compensate but the other vital issues, particularly about the boundary awards, accession of states, and the Kashmir question produced damaging consequences for Pakistan.

\subsection{The $3^{\text {rd }}$ June Plan (Mountbatten Plan)}

Ultimately, after the negotiations and consultations with Indian Leadership, Lord Mountbatten flew to London in May 1947 to discuss the procedure of the transfer of power. The actual story was that Lord Mountbatten had carried a plan which was approved by the British Cabinet. It is known as the $3^{\text {rd }}$ June Plan or Mountbatten Plan. According to the provisions of the Mountbatten Plan, Muslim and Non-Muslim members of the Punjab Assembly met separately on June 23, 1947. The net result of the voting was the partition of the provinces. Boundary commissions were set up to demarcate the boundaries of Punjab. Both Congress and Muslim League leadership agreed to abide by the awards of the boundary commissions and to enforce it (Sen, 1978: 176). The commission was to consist of two representatives of India and two of Pakistan with an impartial member (Cyril Radcliffe) as Chairman. In case of a conflict between the representatives of India and Pakistan, the Chairman will decide the matter (Malik, 2005).

The Boundary Commission was instructed to demarcate the boundaries of the two parts of Punjab based on the contiguous Muslim and non-Muslim majority areas. In doing so, it was also asked to take into account other factors. The basis of determining Muslim/non-Muslim majority areas was the 1941 census (Viceroy's Conference Paper, 17 May 1947). Terms of reference for the boundary commission were ambiguous. For instance, it was not specified whether a district or a tehsil was the basic administrative unit for "ascertaining the contiguous majority areas of Muslims and non-Muslims." The term "other factors" was also vague.

\subsection{The Punjab Award (Radcliffe Award)}

The Radcliffe stated in his report containing the territorial award that due to the conflicting opinions of my colleagues, an agreed solution of the territorial problem was not to be achieved (Nawaz, 2011: 621). He further stated in paragraph 9 that, the task to draw a boundary line in Punjab was very difficult. All respective parties claimed a vast tract of territory but in my opinion debatable area lies in and around the Sutlej and Beas rivers on the one side and the river Ravi on the other. The demarcation of the boundary in this area was more complicated due to the existing canal system which is so important for the life of Punjab.

In paragraph 10, he stated that he had thought for a long time to demarcate Muslim majority areas located in the east of the Sutlej River and the angle of the Beas and Sutlej rivers. But in his judgment, it would not be in the interests of either state to include these areas in West 
Punjab as there were also other factors such as disruption of the water system and railway communication that could displace the primary claim of contiguous majorities.

Furthermore, he stated in paragraph 11 that it was not possible to preserve the Upper Bari Doab irrigation system without division, located between Madhopur (situated in the Tehsil Pathankot of the district of Gurdaspur) and the western border of the district of Lahore. Although he had made some minor changes in the boundary between Lahore and Amritsar districts to minimize the consequences of this severance. (Nawaz, 2011: 623; Qureshi, 1965: 273).

Figure-1: Punjab after Partition (August 15, 1947)

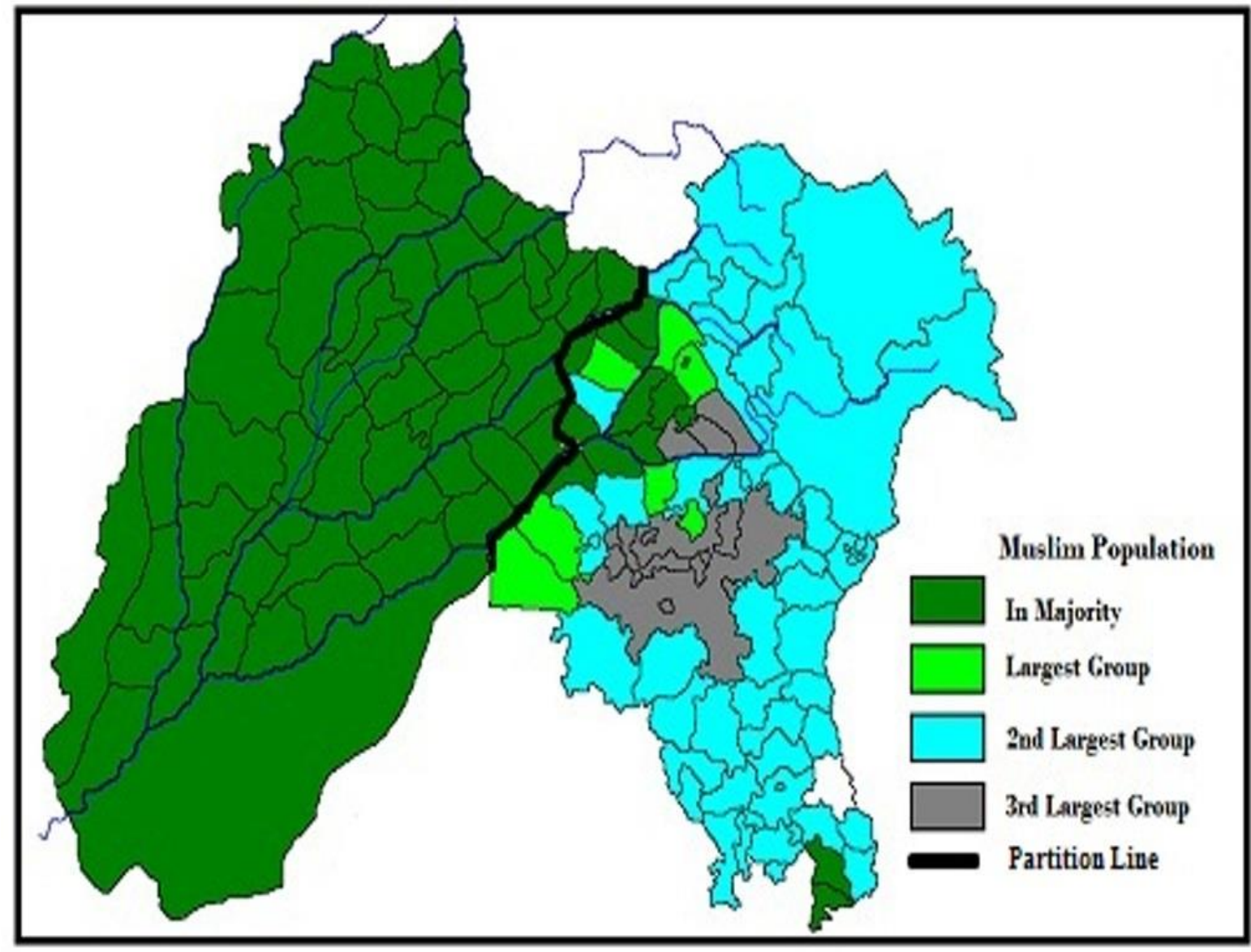

The mandate of the boundary commission was to demarcate the boundaries of Punjab based on the contiguous Muslim and non-Muslim majority areas but, the Radcliffe Award gave several Muslim majority areas to India and not a single Hindu majority area was given to Pakistan. If the justification of this act is searched in the phrase "other factors," it is very strange that the other factors worked totally in favour of India and against Pakistan. Two contiguous Muslim majority tehsils in Gurdaspur district, Gurdaspur and Batala, along with Pathankot tehsil were given to India to provide a land route to the state of Jammu and Kashmir. Ajnala, a Muslim majority tehsil of district Amritsar, was also given to India. Two contiguous Muslim majority tehsils of district Jullaudhar, Nakodar, and Jullundhar, which are located in the angle of the River Beas and Sutlej, were also allocated to India. Zera and Ferozpur were two other Muslim majority tehsils in Ferozpur district which are located east of the Sutlej River, were also allotted to India (Malik, 2005; Hajazi, 2015). Detail of these contiguous Muslim majority areas is given in the following table: 
Table 1: Muslim Majority Areas according to the Census of 1941

\begin{tabular}{|l|c|c|c|c|c|c|}
\hline District / Tehsil & Area Km ${ }^{2}$ & $\begin{array}{c}\text { Total } \\
\text { Population }\end{array}$ & $\begin{array}{c}\text { Muslims } \\
(\% \text { age })\end{array}$ & $\begin{array}{c}\text { Hindus } \\
(\% \text { age })\end{array}$ & $\begin{array}{c}\text { Sikhs } \\
(\% \text { age })\end{array}$ & $\begin{array}{c}\text { Christian } \\
(\% \text { age })\end{array}$ \\
\hline Gurdaspur* & 4,723 & $1,153,511$ & $\begin{array}{c}589,923 \\
(51.14)\end{array}$ & $\begin{array}{c}290,734 \\
(25.21)\end{array}$ & $\begin{array}{c}131,561 \\
(11.41)\end{array}$ & $\begin{array}{c}50,262 \\
(4.36)\end{array}$ \\
\hline Gurdaspur** & 1,287 & 328,819 & $\begin{array}{c}171,498 \\
(52.16)\end{array}$ & $\begin{array}{c}57,281 \\
(17.42)\end{array}$ & $\begin{array}{c}76,695 \\
(23.32)\end{array}$ & $\begin{array}{c}22,506 \\
(6.84)\end{array}$ \\
\hline Batala ** & 1,235 & 380,053 & $\begin{array}{c}209,277 \\
(55.07)\end{array}$ & $\begin{array}{c}33610 \\
(8.84)\end{array}$ & $\begin{array}{c}116,413 \\
(30.63)\end{array}$ & $\begin{array}{c}20,670 \\
(5.44)\end{array}$ \\
\hline Jullandur* & 3,476 & $1,127,190$ & $\begin{array}{c}509,804 \\
(45.23)\end{array}$ & $\begin{array}{c}311,010 \\
(27.59)\end{array}$ & $\begin{array}{c}298,741 \\
(26.50)\end{array}$ & $\begin{array}{c}5,971 \\
(0.53)\end{array}$ \\
\hline Jullandur** & 1,008 & 443,010 & $\begin{array}{c}226,623 \\
(51.16)\end{array}$ & $\begin{array}{c}123,718 \\
(27.93)\end{array}$ & $\begin{array}{c}86,996 \\
(19.64)\end{array}$ & $\begin{array}{c}4,656 \\
(1.05)\end{array}$ \\
\hline Nakodar** & 945 & 228,783 & $\begin{array}{c}135,918 \\
(59.41)\end{array}$ & $\begin{array}{c}39,766 \\
(17.38)\end{array}$ & $\begin{array}{c}52,037 \\
(22.75)\end{array}$ & $\begin{array}{c}929 \\
(0.41)\end{array}$ \\
\hline Ferozpur* & 10,523 & $1,423,076$ & $\begin{array}{c}641,448 \\
(45.07)\end{array}$ & $\begin{array}{c}287,733 \\
(20.22)\end{array}$ & $\begin{array}{c}479,486 \\
(33.69)\end{array}$ & $\begin{array}{c}11,031 \\
(0.78)\end{array}$ \\
\hline Ferozpur ** & 1,761 & 290,286 & $\begin{array}{c}160,371 \\
(55.25)\end{array}$ & $\begin{array}{c}53,520 \\
(18.44)\end{array}$ & $\begin{array}{c}70.782 \\
(24.38)\end{array}$ & $\begin{array}{c}3,847 \\
(1.33)\end{array}$ \\
\hline Zira ** & 1,279 & 210,819 & $\begin{array}{c}137,586 \\
(65.26)\end{array}$ & $\begin{array}{c}18,863 \\
(8.95)\end{array}$ & $\begin{array}{c}50,209 \\
(23.82)\end{array}$ & $\begin{array}{c}3,801 \\
(1.80)\end{array}$ \\
\hline Amritsar* & 4,043 & $1,413,876$ & $\begin{array}{c}657,695 \\
(45.52)\end{array}$ & $\begin{array}{c}217,431 \\
(15.38)\end{array}$ & $\begin{array}{c}510,845 \\
(36.13)\end{array}$ & $\begin{array}{c}25,330 \\
(1.79)\end{array}$ \\
\hline Ajnala** & 1,083 & 237,049 & $\begin{array}{c}140,939 \\
(59.46)\end{array}$ & $\begin{array}{c}15,415 \\
(6.50)\end{array}$ & $\begin{array}{c}67,986 \\
(28.68)\end{array}$ & $\begin{array}{c}12,708 \\
(5.36)\end{array}$ \\
\hline
\end{tabular}

Source: (Government of India, 1943)

District*

Tehsil**

The reason given by Redcliff that contiguous Muslim majority areas were given to India to avoid the disruption of the water system is very thin. All the canals taken off from the Ferozpur Headworks except the Bikaner Canal irrigated mostly Muslim majority areas should have gone to Pakistan. By awarding them to India, he not only disrupted a water system but also violated the principles of International Law. Moreover, he drew the boundary line in such a manner that it included Ferozpur Headworks in India (Malik, 2005).

Radcliffe line cut across the River Ravi and the Sutlej and divided Upper Bari Doab Canal (UBDC) system into parts, leaving its headworks at Madhopur in India and irrigated area in largely Muslim majority tehsils of Batala, Gurdaspur, Ajnala, Lahore, and Kasur. The severance of this canal impacted the livelihood of millions of the poor people of West Punjab. West Punjab depended far more than East Punjab upon the system of canal irrigation, which was among the most beneficial projects the British had undertaken in the subcontinent. The life-giving waters of the Indus System changed an arid and semi-arid area of Punjab into the green fields. By giving complete control of the crucial canal headworks to India, the Radcliffe award put the economy of West Pakistan in danger.

\subsection{Punjab Partition Committee and the Tribunal Awards}

Two bodies (Punjab Partition Committee and Arbitral Tribunal) were established to divide physical assets. The Punjab Partition Committee dealt with the matters related to the division of the Punjab. It consisted of two minister-level members, one from the East Punjab and the 
other from West Punjab, presided over by the Governor. Sardar Shaukat Hayat represented West Punjab and Sawarn Singh East Punjab. In case of disagreement, the Partition Committee was to make a reference to the Arbitral Tribunal for an award. The Partition Committee had separate committees for different subjects. Committee B was on 'Division of Physical Assets' and for settling questions relating to the future management of joint assets including the water shares. It had an equal number of members ${ }^{2}$ representing both provinces of East and West Punjab. Punjab Partition Committee received a unanimous report of the Committee B on the issue of post-partition water shares of East Punjab and West Punjab, stating in paragraph 15 as: "The Committee is agreed that there is no question of varying the authorized shares of water to which the two zones and the various canals are authorized" (Ali, 1973).

Partition Committee discussed the unanimous report of the Committee B on July 28, 1947. According to Ali (1973: 318), "the Partition Committee maintained the pre-partition shares of West Punjab and East Punjab in canal waters". It appointed two members of Committee B to implement the provisions in paragraph 15 concerning the maintenance of supplies to each zone and canal".

On the release of the Boundary Award, India became the Upper riparian by having maneuvered control of Madhopur and Ferozpur Headworks. She had her hand on the spigot of irrigation supply to west Punjab's 11 large canal networks. It was a matter of life and death for West Punjab to ensure a continued flow of her post-partition water shares. It required a formal written agreement specifying water shares of East Punjab and West Punjab. A formal agreement required reference to Partition Committee. India as the upper riparian did not need such an agreement. However, West Punjab needed it more. It was for her to move the matter to the Partition Committee. In case of disagreement, the Committee was to refer the matter to the Arbitral Tribunal for an award. But no such reference was made. As Ali (1973: 318) described "The question of the apportionment of the irrigation waters of the rivers common to India and Pakistan was not referred to the Partition Committee because there was no dispute to refer".

Michel (1967: 195) stated that conflict over the management of water between East Punjab (India) and West Punjab (Pakistan) started in autumn of 1947 due to the reduction of monsoon flow in the Indus river system. To resolve the conflict, the chief engineers of both provinces negotiated and reached a "Standstill Agreement" on 18 December 1947. The Agreement maintained the existing discharges from the headworks on Upper Bari Doab Canal, the Bahawalpur Canal, and the Dipalpur Canal until March 31, 1948, and both parties would negotiate for further agreement. Both parties also hoped that a solution to the problem would be achieved within the due period but West Punjab did not take any step within the period scheduled by the Agreement.

\section{Water Management, Dispute, and the Agreement}

\subsection{Indian Action of April 1, 1948}

On April 1, 1948, both the Arbitral Tribunal and Standstill Agreement ceased to exist; the Government of East Punjab stopped water supplies in all canals that irrigated agricultural land in Pakistan. These were the Dipalpur Canal System, Central Bari Doab Canal (CBDC), and the Bahawalpur State Distributary. Of this action, Sir Patrick Spens ${ }^{3}$ said before the joint meeting of the East Indian Association and the Overseas League in London on February 23, 1955, that some order should be made about the continued flow of waters in the canal systems. But the 
Attorney Generals of India and Pakistan told that there would be no interference in the existing flow of water. Our award was made based on this fact which was published at the end of March 1948. He further said that he could say nothing except that he was much upset about the grave interference with the flow of water within a day or two based on which our award was made (Ali, 1973: 320).

Indian action, closing of the canal's waters to Pakistan at the most critical time when wheat crop was near to mature, more aggravated the already tense political relations between the two nations. According to Bengali (2009), the Indian action affected about 1.7 million acres of agricultural land in Pakistan resulting in a loss of about one million tons of wheat production. Furthermore, Lahore, the largest city of West Punjab, was deprived of its water for municipal use and Power supply from the Mandi Hydropower Project to Pakistan was also cut off. Gulhati (1973: 60) admitted that due to the Indian action "some irrigation channel near Lahore became dry". There were various opinions about the Indian action in the contemporary press. For instance, being an upper riparian, India claimed its sovereign rights on Upper Bari Doab Canal. It used this weapon to pressurize Pakistan to withdraw its claims about Jammu and Kashmir; it tried to highlight the dependence of Pakistan on India in the hope of forcing reconciliation (Michel, 1967: 195). However, Arora (2007: 53) argues that East Punjab cut off the canal's water without the prior consent of the central government of India.

\subsection{Joint Statement of May 4, 1948 (Delhi Agreement)}

All Pakistan pleas, appeals, and protests to India for reopening the closed canals produced no result. Under this disastrous situation, Pakistan sent a delegation to Delhi on May 3, 1948, to solve the problem under the headship of the Finance Minister, Mr. Ghulam Muhammad (Ali, 1973). Its members were Mian Mumtaz Daultana and Sardar Shaukat Hayat, West Punjab Ministers for Finance, and Revenue respectively. The Indian team was led by Prime Minister Jawahar Lal Nehru including as members Mr. N.V. Gadgil, Minister for Works, Mines and Power, Government of India, and Mr. Swaran Singh, Irrigation Minister, East Punjab. Pakistan protested against the stoppage of water in her canals in blatant breach of the Partition Committee Agreement and contrary to repeated declarations by Indian representatives. But it failed to cut the ice. The Government of East Punjab made it clear that the flow of water could not be restored unless West Punjab acknowledged that it had no right to the water (Gulhati, 1973; Malik, 2005).

It was not acceptable to Pakistan and India was not agreeing to Pakistan's proposal that the two governments refer the matter to the International Court of Justice for judgment on their water rights. There was a deadlock. Ghulam Muhammad requested Lord Mountbatten to interfere in the matter. In response, Lord Mountbatten consulted with Jawaharlal Nehru. A statement was then put before the members of Pakistan's delegation and they were asked that 'for the restoration of the flow of water, they have to sign it without changing a word or comma. On May 4, 1948, it was signed by Ghulam Muhammad and two ministers of the West Punjab on behalf of Pakistan and Jawaharlal Nehru and two ministers of East Punjab on behalf of India (Ali, 1973; Malik, 2005; Palijo, 2011: 31-32).

The statement declared that, apart from the question of law involved, both governments were willing to solve the problem in a practical spirit. The government of East Punjab would gradually reduce water supply to the Central Bari Doab and Dipalpur canals to give sufficient time to the government of West Punjab to establish alternative sources (Gulhati, 1973). The 
statement further declared that water was being restored and West Punjab was to deposit in escrow such "ad hoc amount as may be specified by the Prime Minister of India" to cover certain disputed payments. And after an examination of the legal and other issues involved by each side, a further meeting would take place. In conclusion, it was hoped that a friendly solution would be found (Ali, 1973; Malik, 2005).

However, 'the Joint Statement' restored the flow of water to Pakistan but at a high cost. Firstly, Pakistan was to pay a large amount of money to India for the transportation of water through India. Secondly, India was to be permitted to decrease the supply of water to Pakistan gradually. Although Pakistan had signed the statement, she was not satisfied with its provisions therein, and not only did object to the Statement itself but also the atmosphere in which it was signed. On the other side, India was satisfied because she considered it an international agreement, and completely refuted Pakistan's position that the agreement was invalid and it was signed under heavy pressure.

The signing of the joint statement was a grave mistake by Pakistan because, thereafter, India made the contents of the joint statement the basis of all further negotiations. The Indian position so hardened that in the meeting of 29 May 1950 at Karachi, the Indian delegation declared that India intended to appropriate the entire useable flow of the Sutlej, Beas, and Ravi besides taking a further 10,000 cusecs from the Chenab through a tunnel at Marhu (Malik, 2005). Looking back with the advantage of hindsight, it can be stated that India stuck to its position from day one and forced Pakistan to make one concession after another until it was able to extract every bit of what it had demanded and much more besides.

From July 1950 onward, Pakistan refused to deposit the sum, specified in the Joint Statement (Delhi Agreement), and stated that the amount would be paid only when the dispute would be taken to any international organization, such as the International Court of Justice or Security Council of United Nations. Pakistan also rejected the Joint Statement of May 4, 1948, and stated that the statement was signed under 'duress' and at the same time, it had given notice of its termination (Gulhati, 1973: 80). From that stage, a deadlock was developed between the two countries. The process of negotiations restarted at the end of the year 1951 when both India and Pakistan accepted the offer of good offices of the World Bank. After decade long hectic negotiations, the conflict resolved through by signing the Indus Waters Treaty under the auspices of the World Bank on September 19, 1960.

\section{Conclusion}

In response to the freedom movement of the Indian masses, the British Government eventually decided to leave India. British Prime Minister Clement Attlee made a declaration in House of Commons on $20^{\text {th }}$ February 1947 that the process of transfer of power will be completed by June 1948. But in the $3^{\text {rd }}$ June Plan, it was declared that transfer of power would be completed by August 1947. At the same time, the partition of the Muslim majority provinces of Bengal and Punjab was also incorporated to complete the secret deal between INC and Mountbatten. Two boundary commissions were set up under the chairmanship of Sir Cyril Radcliffe to divide both provinces. The Radcliffe announced his Punjab award on August 17, 1947, two days after independence although it was due to be announced on the $10^{\text {th }}$ of August. It was delayed to conceal a conspiracy behind the partition.

The mandate of Punjab Boundary Commission was to set the limits of the boundaries of East 
and West Punjab according to the contiguous areas of the Muslim and non-Muslim majority. Contrary to that the Radcliffe Award assigned various Muslim majority areas to India and never assigned a single area of the Hindu majority to Pakistan. Due to the injustice done in the Award, seven contiguous Muslim majority tehsils were awarded to India. It is worth noting that these areas were allotted to India to give the control of irrigation supplies because both headworks at Modopur and Ferozpur were situated in those Muslim majority areas. By granting complete control of the crucial canal headworks to India, the Radcliffe award put the economy of West Pakistan in danger. This hypothesis proved right on $1^{\text {st }}$ April 1948 when India cut off the supply of water to every canal flowing into Pakistan from Madhopur and Ferozpur headworks.

During this disastrous situation, Pakistan sent a delegation to Delhi on May 3, 1948, to solve the problem under the headship of the then Finance Minister, Mr. Ghulam Muhammad. The said delegation met with their Indian counterparts in Delhi where a joint statement was signed on April 4, 1948, in which India agreed to restore the flow of water provided, Pakistan would deposit some amount as escrow to cover certain disputed payments. The signing of the joint statement was a grave mistake by Pakistan because, thereafter, India made the contents of the joint statement the basis of all future negotiations. Due to differences over the interpretation of the Joint Statement of May 4, 1948, Pakistan terminated it by stating that it was signed under 'duress' but India rejected these allegations. Ultimately, under the auspices of the World Bank, the dispute was resolved by signing the Indus Water Treaty in 1960.

\section{References}

Ahmad, K. S. (1964). A Geography of Pakistan. Oxford University.

Ali, C. M. (1973). The Emergence of Pakistan. Research Society of Pakistan, University of Punjab.

Arora, R. K. (2007). The Indus Water Treaty Regime. Mohit.

Bengali, K. (2005). The Politics of Managing Water. Oxford University.

Brecher, M. (1959). Nehru: A Political Biography. Oxford University.

Chatterjee, C. (2018). The Sikh Minority and the Partition of the Punjab 1910-1947. Manohar.

Cheema, P. I. (2000, September). The Politics of the Punjab Boundary Award. University of Heidelberg: South Asia Institute; Department of Political Science. http://www.archive.ub.uni.heidelberg.de/volltextserver/volltexte/hpsacpl.pdf

Collins, L., \& Lapierre, D. (1997). Freedom at Midnight. Harper Collins (Paperback edition). Government of India (1943). Census of India 1941 (Part I). https://www.piketty.pse.ens.fr/files/ideologie/data/CensusIndia/CensusIndia1941/Ce nsus\%20of\%20India\%201941.pdf

Gulhati, N. D. (1973). Indus Water Treaty: An Exercise in International Mediation. Allied.

Hajazi, N. (2015). Midnight's Furies: The Deadly Legacy of India's Partition. Houghton Mifflin Harcourt.

Khan, H. (2009). Constitutional and Political History of Pakistan. Oxford University.

Khan, Y. (2017). The Great Partition: The Making of India and Pakistan. Yale University.

Khurram, M., Munir, M. H., \& Munir, M. F. (2018). Manual of Partition's Laws. Popular Law Book House.

Malik, B. A. (2005). Indus Water Treaty in Retrospect. Brite Books.

Michel, A. A. (1967). The Indus River: A Study of the Effects of Partition. Yale University.

Mountbatten, P. (2008). India Remembered: A Personal Account of the Mountbattens During the Transfer of Power. Pavilion Books. 
Nawaz, J. ((2011). Pakistan's Bleeding Wounds; Fatal British Conspiracy. Allied Book.

Palijo, R. B. (2011). Sindh-Punjab Water Dispute 1859-2003. Centre for Peace and Civil Society.

Pardesi, M. S., \& Ganguly, S. (2019). Violent Punjab, quiescent Bangal and partition of India. Commonwealth \& Comparative Politics, 57(1), 1-30. https://doi.org/10.1080/14662043.2019.1554232

Pyarelal. (1956). Mahatama Gandhi: The Last Phase. Navajivan.

Qadri, J. S. (1983). Creation of Pakistan. Wajidalis.

Qureshi, I. H. (1965). The Struggle for Pakistan. BCC \& T. Press, University of Karachi.

Salman, S. M., \& Uprety, K. (2002). Conflict and Cooperation On South Asia's International Rivers. The World Bank.

Sayeed, K. B. (1998). Pakistan: The Formative Phase 1857-1948. Oxford University.

Sen, D. S. (1978). The Bith of Pakistan. Saddiq.

Tucker, S. F. (1950). While Memory Serves. Cassel.

Viceroy's Conference Paper. (17 May 1947) V. C. P. 54, R/3/1/150: ff 1-9. https://archive.org/stream/constitutionalre06nich/constitutionalre06nich_djvu.txt

Wolpert, S. (1984). Jinnah of Pakistan. Oxford University.

\section{Notes:}

${ }^{1}$ Tara Singh was called Master because he was a school teacher in Rawalpindi. He had lost many members of his own family in the violence. He had provoked passions for revenge (Malik, 2005: 53).

${ }^{2}$ Committee B consisted of two members, M. R. Sajdev from East Punjab and Syed Yaqub Shah from West Punjab (ibid).

${ }^{3}$ Sir Patrick Spens was an eminent lawyer of United Kingdom. He was appointed as the Chairman of the Arbitral Tribunal to decide the conflicting matters referred by the Partition Committee (Ali, 1973: 320). 